\title{
Role of vaginal progesterone in reducing the rate of preterm labour in women with a sonographic short cervix
}

\author{
Kirtirekha Mohapatra*, Subhra Ghosh, Rabinarayan Dash, Balaram Sahoo
}

\author{
Department of Obstetrics \& Gynaecology, SCB Medical College, Cuttack, Odisha, India
}

Received: 08 November 2015

Accepted: 23 November 2015

\author{
*Correspondence: \\ Dr. Kirtirekha Mohapatra, \\ E-mail: kirtirekhamohapatra@gmail.com
}

Copyright: (C) the author(s), publisher and licensee Medip Academy. This is an open-access article distributed under the terms of the Creative Commons Attribution Non-Commercial License, which permits unrestricted non-commercial use, distribution, and reproduction in any medium, provided the original work is properly cited.

\begin{abstract}
Background: Preterm labour is responsible for not only neonatal morbidity and mortality but also has long term consequences .Till now there is no effective method of prevention. Progesterone has shown promising result. But ideal candidate, ideal route and when to start the treatment are still in dilemma. The present study was undertaken to know the role of progesterone on pregnant women with sonographically short cervix.

Methods: This prospective case control study was started on 100 pregnant women with sonographic short cervix $(\leq 2.5 \mathrm{~cm})$ and between $19-29$ weeks of gestation. 60 women, some with history of midtrimester abortion or preterm labour and some without this history were treated as cases and were given vaginal progesterone pessary $200 \mathrm{mg}$ once daily till rupture of membrane or onset of labour or up to 36 weeks of gestation whichever is earlier. 40 women without any history of midtrimester abortion or preterm labour were treated as control and followed up.

Results: Among the cases $18.3 \%$, delivered preterm and $81.7 \%$ were term deliveries. Respective proportions among control were $40 \%$ and $60 \%$ respectively. 26 among the cases and all women of control group did not have history of preterm labour and mid trimester abortion. In the case group $26.9 \%$ and in the control group $40 \%$ had preterm deliveries. Though the proportion of labour was lower among the cases it is not statistically significant $(p=0.276)$. There is mean prolongation of gestational age by $8.4 \pm 1.29$ weeks in case group in present pregnancy compared the previous one in cases with history of preterm labour and midtrimester abortion which was statistically significant .When neonatal complication are compared there is no significant difference between the two groups.

Conclusions: Vaginal progesterone started from midtrimester in pregnant ladies with short cervix with previous history of midtrimester abortion or preterm labour is effective in reducing the rate of preterm birth.
\end{abstract}

Keywords: Preterm labour, Progesterone, Short cervix

\section{INTRODUCTION}

Preterm birth defined as child birth occurring at less than 37 weeks. It is a major determinant of neonatal mortality and morbidity and has long term adverse consequences. ${ }^{1,2}$ Of all early neonatal deaths that are not related to congenital malformation, $28 \%$ are due to preterm labour. ${ }^{3}$ Morbidities like cerebral palsy, sensory deficits, learning disabilities and respiratory illnesses extend to later life resulting in enormous physical, psychological and economic costs. ${ }^{4,5}$ About $9.6 \%$ of all birth around the world are preterm (2005) i.e. about 12.9 millions. Africa and Asia contributes to $85 \%$ of it. ${ }^{6}$ Preterm labour is multifactorial in origin hence called 'Preterm Parturition Syndrome' and efforts to prevent it is largely unsuccessful. Recent date suggests that progesterone may be important in maintaining uterine quiescence by limiting the production of prostaglandins and inhibiting the expression of contraction associated protein genes within the myometrium. ${ }^{7-9}$ ACOG recommends progesterone supplementation to be restricted to women with singleton pregnancy and a previous history of 
spontaneous preterm birth. ${ }^{10}$ At present there is little information available regarding the optimal dose of progesterone , mode of administration ,gestational age to start therapy or duration of therapy. There is evidence that pregnant women with cervical shortening may also benefit although this indication is not yet approved by FDA.

\section{METHODS}

This is a prospective interventional case control study conducted on 100 subjects in the department of $\mathrm{O} \& \mathrm{G}$, S.C.B. Medical College, Cuttack, Odisha, India.

Inclusion criteria are singleton pregnancy with gestational age between 19 and 29 weeks and asymptomatic with transvaginal sonographic cervical length between 10-25 mm. Pregnant women with planned circlage, acute cervical dilation, vaginal bleeding, progesterone allergy, uterine malformation known or suspected clinical chorioamnionitis were excluded from the study. A detailed history especially obstetric history regarding mid trimester abortion or preterm labour was taken and physical examination was done. Cervical length was measured by TVS in empty bladder.

100 candidates with short cervix $(\leq 25 \mathrm{~mm})$ were taken for the study. 60 women with short cervix were selected as cases and treated with micronized vaginal progesterone $200 \mathrm{mg}$ once daily till 36 weeks, rupture of membrane or onset of labour whichever is earlier.In this group some women had prior history of spontaneous preterm labour or mid trimester abortion. Other 40 women without any history of spontaneous preterm labour or mid trimester abortion were followed up till delivery. Primary outcome of this study was preterm birth before 37 weeks. The key secondary outcomes were neonatal morbidities.

Statistical analysis was performed by SPSS-16 software. Descriptive analysis like mean, SD has been carried out for comparison of mean levels of different parameters under study. Comparison of mean of characteristics between case and control has been undertaken by independent sample $-t$ - test. Test of association of categorical variables with case and control has been studied with the help of chi-square Test.

\section{RESULTS}

One hundred pregnant women participated in the study. However there is no significant difference in age, gestational age at first presentation and cervical length in case and control group. Prior history of spontaneous preterm labour, midtrimester abortion was there in 34 (56.7\%) pregnant women in case group. No pregnant women of control group had such history. Mean duration of treatment in case group was 10.3 weeks.

Table 1: Demographic characteristics of women.

\begin{tabular}{|c|c|c|c|c|}
\hline characteristics & $\begin{array}{l}\text { Case } \\
(n=60)\end{array}$ & $\begin{array}{l}\text { Control } \\
(n=60)\end{array}$ & $\begin{array}{l}\text { Indep } \\
\text { sampl } \\
\text { test }\end{array}$ & $\begin{array}{l}\text { adent } \\
\text { 't' } \\
\text { 'p' }\end{array}$ \\
\hline Mean age & $\begin{array}{l}25.5 \pm \\
2.825^{*}\end{array}$ & $\begin{array}{l}24.35 \pm \\
1.703^{*}\end{array}$ & 2.308 & 0.63 \\
\hline $\begin{array}{l}\text { Obstetric } \\
\text { history H/O } \\
\text { preterm birth } \\
\text { and } \\
\text { midtrimester } \\
\text { abortion }\end{array}$ & $\begin{array}{l}34 \\
(56.7 \%)\end{array}$ & 0 & & 0.06 \\
\hline $\begin{array}{l}\text { Gestational } \\
\text { age at first } \\
\text { presentation }\end{array}$ & $\begin{array}{l}25.1 \pm \\
2.1^{*}\end{array}$ & $\begin{array}{l}24.3 \pm \\
1.6^{*}\end{array}$ & 1.927 & 0.05 \\
\hline $\begin{array}{l}\text { Cervical } \\
\text { length }\end{array}$ & $\begin{array}{l}2.282 \pm \\
0.116^{*}\end{array}$ & $\begin{array}{l}2.270 \pm \\
0.097^{*}\end{array}$ & 0.527 & 0.60 \\
\hline $\begin{array}{l}\text { Duration of } \\
\text { treatment }\end{array}$ & $10.3 \pm 3.1$ & - & & - \\
\hline
\end{tabular}

Values are expressed in Mean \pm SD

Table 2: Proportion of Preterm birth by subject Groups.

\begin{tabular}{|c|c|c|c|c|c|c|c|}
\hline \multirow{2}{*}{ Gestational age at delivery } & \multicolumn{2}{|c|}{ Case } & \multicolumn{2}{|c|}{ Control } & \multicolumn{2}{|c|}{ Total } & \multirow{2}{*}{ Chi-Square and 'p' value } \\
\hline & No. & $\%$ & No. & $\%$ & No. & $\%$ & \\
\hline Preterm & 11 & 18.3 & 16 & 40 & 27 & 27 & \multirow{3}{*}{$\begin{array}{l}\chi^{2}=5.716 \\
' p^{\prime}=0.017\end{array}$} \\
\hline Term & 49 & 81.7 & 24 & 60 & 73 & 73 & \\
\hline Total & 60 & 100 & 40 & 100 & 100 & 100 & \\
\hline
\end{tabular}

Table 2 shows that among the cases $18.3 \%$ delivered preterm and $81.7 \%$ were terms and the respective proportion among control was $40 \%$ and $60 \%$. The chisquare test of independence revealed higher association with term birth among cases $(\mathrm{p}=0.0170)$.
Table 3 shows that the relative risk of preterm among cases was 0.607 while that among the control was 1.802 . This implied lower relative risk of preterm birth among the cases is seen. 
Table 3: Risk estimate for preterm in case and control.

\begin{tabular}{|llll|}
\hline $\begin{array}{l}\text { Risk Estimate of } \\
\text { Preterm/Term }\end{array}$ & Value & $\begin{array}{l}\text { 95\% Confidence } \\
\text { Interval }\end{array}$ & Upper \\
\hline $\mathrm{n}=100$ & & Lower & Upp \\
\hline $\begin{array}{l}\text { For cohort Group } \\
=\text { Case }\end{array}$ & 0.607 & 0.375 & 0.983 \\
\hline $\begin{array}{l}\text { For cohort Group } \\
=\text { Control }\end{array}$ & 1.802 & 1.146 & 2.835 \\
\hline
\end{tabular}

Table 4 shows that there is a mean prolongation of gestational age by $8.4 \pm 1.290$ weeks in case group in present pregnancy compared to the previous one which was found to be statistically significant.

Table 5 shows that 66 subjects, 26 among the cases and 40 among the controls did not have history of preterm labour or midtrimester abortion. In the case group $26.9 \%$ and in the control group $40 \%$ had preterm delivery. Though the proportion of preterm labour was lower among the cases it is not statistically significant ( $\mathrm{p}=$ 0.276)

Table 4: Comparison of GA at delivery with GA at previous delivery or abortion.

\begin{tabular}{|c|c|c|c|}
\hline \multirow{2}{*}{$\begin{array}{l}\text { Gestational age in } \\
\text { weeks }\end{array}$} & \multicolumn{3}{|c|}{$\begin{array}{l}\text { Paired Samples Statistics } \\
(\mathrm{n}=\mathbf{3 4})\end{array}$} \\
\hline & Mean & $\begin{array}{l}\text { Std. } \\
\text { Deviation }\end{array}$ & 'P' \\
\hline $\begin{array}{l}\text { GA at delivery in } \\
\text { present pregnancy }\end{array}$ & 37.13 & 1.697 & \multirow{2}{*}{$\begin{array}{l}\mathrm{p}= \\
0.00\end{array}$} \\
\hline $\begin{array}{l}\text { GA at previous } \\
\text { delivery or abortion }\end{array}$ & 28.73 & 6.828 & \\
\hline $\begin{array}{l}\text { Mean difference } \pm \text { S.E. } \\
\text { in weeks }\end{array}$ & \multicolumn{3}{|c|}{$8.4 \pm 1.290$} \\
\hline
\end{tabular}

S.E.- Standard Error

Table 5: Preterm birth among women with no h/o preterm birth or midtrimester abortion by groups.

\begin{tabular}{|c|c|c|c|c|c|c|c|}
\hline \multirow{2}{*}{ Gestational age at delivery } & \multicolumn{2}{|c|}{ Case } & \multicolumn{2}{|c|}{ Control } & \multicolumn{2}{|c|}{ Total } & \multirow{2}{*}{ Chi-Square and 'p' value } \\
\hline & No. & $\%$ & No. & $\%$ & No. & $\%$ & \\
\hline Preterm & 7 & 26.90 & 16 & 40.00 & 23 & 34.80 & \multirow{3}{*}{$\begin{array}{l}\chi^{2}=1.187 \\
\mathrm{p}^{\prime}=0.276\end{array}$} \\
\hline Term & 19 & 73.10 & 24 & 60.00 & 43 & 65.20 & \\
\hline Total & 26 & 100.00 & 40 & 100.00 & 66 & 100.00 & \\
\hline
\end{tabular}

While comparing the neonatal complication like RDS, LBW, VLBW, no complication was seen in $75 \%$ and $60 \%$ in case and control group respectively. There is no statistically significant difference in complications among the case and control group.
Table 6 shows that percentage of term delivery has increased with the increase in cervical length both among cases and controls.

Table 6: Comparison of GA at delivery with cervical length.

\begin{tabular}{|c|c|c|c|c|c|c|c|}
\hline \multirow{3}{*}{$\begin{array}{l}\text { Cervix } \\
\text { Length } \\
\text { (Cm.) }\end{array}$} & \multirow{3}{*}{ Gestational Age } & \multicolumn{4}{|l|}{ Group } & \multirow{2}{*}{\multicolumn{2}{|c|}{ Total }} \\
\hline & & Case & & Control & & & \\
\hline & & Number & $\%$ & Number & $\%$ & Number & $\%$ \\
\hline \multirow{3}{*}{$2-2.25$} & Term & 17 & 73.9 & 6 & 42.9 & 23 & 62.2 \\
\hline & Preterm & 6 & 26.1 & 8 & 57.1 & 14 & 37.8 \\
\hline & Total & 23 & 100 & 14 & 100 & 37 & 100 \\
\hline \multirow{3}{*}{$\begin{array}{l}>2.25- \\
2.5\end{array}$} & Term & 32 & 86.5 & 18 & 69.2 & 50 & 79.4 \\
\hline & Preterm & 5 & 13.5 & 8 & 30.8 & 13 & 20.6 \\
\hline & Total & 37 & 100 & 26 & 100 & 63 & 100 \\
\hline \multirow{3}{*}{ Total } & Term & 49 & 81.7 & 24 & 60 & 73 & 73 \\
\hline & Preterm & 11 & 18.3 & 16 & 40 & 27 & 27 \\
\hline & Total & 60 & 100 & 40 & 100 & 100 & 100 \\
\hline
\end{tabular}


Table 7: Neonatal complications by group.

\begin{tabular}{|c|c|c|c|c|c|}
\hline \multirow{3}{*}{ Complications } & \multicolumn{4}{|c|}{ Group } & \multirow{3}{*}{$\begin{array}{l}\text { Chi- } \\
\text { Square } \\
\text { and 'p' } \\
\text { value }\end{array}$} \\
\hline & \multicolumn{2}{|c|}{ Case } & \multicolumn{2}{|c|}{ Control } & \\
\hline & No & $\%$ & No & $\%$ & \\
\hline No Complication & 45 & 75 & 24 & 60 & \multirow{5}{*}{$\begin{array}{l}\chi^{2}= \\
9.292 \\
\mathrm{p}^{\prime}= \\
0.026\end{array}$} \\
\hline RDS & 5 & 8.3 & 0 & 0 & \\
\hline LBW / VLBW & 7 & 11.7 & 10 & 25 & \\
\hline RDS \& LBW & 3 & 5 & 6 & 15 & \\
\hline Total & 60 & 100 & 40 & 100 & \\
\hline
\end{tabular}

\section{DISCUSSION}

Preterm birth is the leading cause of morbidity and mortality worldwide and prevention is an important healthcare priority. Preterm parturition is caused by multiple etiologies. One of the mechanism of the disease is the ultimate decline in progesterone action, which can present as a clinically silent sonographic short cervix in the midtrimester abortion. ${ }^{11}$ The basis for this hypothesis is that the administration of progesterone receptor antagonist (Mifepristone) to pregnant women lead to cervical priming (which includes shortening of cervix). ${ }^{12-}$ ${ }^{14}$ For these reasons it has been proposed that a progesterone deficiency can be corrected by the administration of this hormone in close anatomic proximity to the cervix thereby preventing preterm labour.

One hundred asymptomatic women with singleton pregnancy with a TVS cervix length $(\leq 25 \mathrm{~mm})$ were included in the study after taking consent. The case groups were given vaginal progesterone and control group were only followed up.

Mean age in the case and control group were $25.5 \pm 2.827$ years and $24.35 \pm 1.703$ years respectively. This is in accordance to the study by Gamze et al whose mean maternal age was $25.38 \pm 4.54$ years. ${ }^{15}$ Mean cervical length in our study was $2.282 \pm 0.116 \mathrm{~cm}$ and $2.270 \pm$ $0.977 \mathrm{~cm}$ in the case and control group respectively which was corroborating with the study by Romero et al. ${ }^{16}$ But in the PREGNANT trial a sonographic short cervix was taken as $10-20 \mathrm{~mm}^{17}$

Mean gestational age of enrollment among cases was $25.1 \pm 2.1$ weeks and among controls $24.3 \pm 1.6$ weeks but in PREGNANT trial asymptomatic women were enrolled at 19-23 weeks of gestation, this is because patients present to us at a later gestational age.

Mean duration of treatment for cases in our study was 10 \pm 3.1 weeks .but the study conducted by da Fonseca et al women with a short cervix $(\leq 15 \mathrm{~mm})$ were treated from 24 to 34 weeks. ${ }^{19}$

Table 2 shows that in our study $18.3 \%$ were preterm and $81.7 \%$ were term among the cases and the respective proportion among control was $40 \%$ and $60 \%$. The study conducted by da Fonseca et al showed the similar results. But in PREGNANT trial patient had a lower rate of preterm birth before 34 weeks than those allocated to placebo $(8.9 \%$ vs $16.1 \%)$ which is much lower than the present study. This may be because their primary endpoint of preterm birth is 34 weeks and they had used $90 \mathrm{mg}$ of progesterone gel instead of pessaries.

Table 4 shows that in our study in the case group, among cases with history of preterm birth or midtrimester abortion gestational age (GA) at delivery $(n=34)$ has a mean of $37.13 \pm 1.697$ weeks and GA at previous preterm delivery or abortion had a mean of $28.73 \pm 6.828$ weeks with a mean prolongation of GA by $8.4 \pm 1.290$ weeks which was found to be statistically significant. In an individual patient metaanalysis women treated with vaginal progesterone had a significant reduction in the rate of preterm birth < 33 weeks (RR: $0.58 ; 95 \%$ CI: 0.42 $-0.80)$.

Table 5 shows that Twenty six among the cases and 40 among the controls with short cervix did not have history of preterm labour; but the preterm delivery was $26.9 \%$ and $40 \%$ in cases and controls respectively. But chisquare test did not reveal any significant association ( $p$ $=0.276$ ) of prevention of preterm labour in a case of short cervix without prior history of preterm labour or midtrimester abortion. But in the trial conducted by da Fonseca et al, patients allocated to receive vaginal progesterone had a lower rate of preterm labour $(19.2 \%$ Vs $34.4 \%$ ). It may be due to late enrollment or small sample size in our study.

Table 6 shows that in our study in the cervix length 2 $2.24 \mathrm{~cm}$, term delivery was $73.9 \%$ and $42.9 \%$ among cases and control respectively. In the cervix length group $2.25-2.5 \mathrm{~cm}$ term delivery among cases was $86.5 \%$ and $69.2 \%$ among the controls. In the study conducted by Timor Tritsch et al the mean cervical length was shorter in cases delivery before 37 weeks than in those delivery at term ( $16.9 \mathrm{~mm} \mathrm{Vs} 31.9 \mathrm{~mm}){ }^{18}$ The percentage of term delivery has increased with the increase in cervical length both among cases and controls in both the studies.

Table 7 shows that neonatal complications were not different in both the groups in our study, where as in PREGNANT trial neonates born to mothers to receive vaginal progesterone gel had a significantly lower frequency of RDS than the placebo group (3\% vs 7.6\%).

\section{CONCLUSIONS}

Progesterone supplementation prevents preterm birth only in one third of cases in ideal circumstances. A better understanding of the molecular mechanism by which progesterone acts to maintain myometrial quiescence and prevent uterine contractions and cervical changes will allow obstetric care provider to develop more effective interventions. 
Funding: No funding sources

Conflict of interest: None declared

Ethical approval: The study was approved by the Institutional Ethics Committee

\section{REFERENCES}

1. Huddy CL, Johnson A, Hope PL. Educational and behavioral problems in babies of 32-35 weeks gestation. Arch Dis Child Fetal Neonatal Ed. 2001;85:23F-8.

2. Wang ML, Dorer DJ, Fleming MP, Catlin EA. Clinical outcomes of near-term infants. Pediatrics. 2004;114:372-6.

3. Lawn JE, Wilczynska-Ketende K, Cousens SN. Estimating the causes of 4 million neonatal deaths in the year 2000. Int J Epidemiol. 2006;35:706-18.

4. Petrou S. The economic consequences of preterm birth during the first 10 years of life. BJOG. 2005;112:10-5.

5. Petrou S, Mehta Z, Hockley C, Cook-Mozaffari P, Henderson J, Goldacre M. The impact of preterm birth on hospital inpatient admissions and costs during the first 5 years of life. Pediatrics. 2003;112:1290-7.

6. WHO bulletin2010:85-31-38

7. Norwitz ER, Robinson JN, Challis JRG. The control of labor. N Engl J Med. 1999;341:660-6.

8. Challis JRG, Matthews SG, Gibb W, Lye SJ. Endocrine and paracrine regulation of birth at term and preterm. Endocr Rev. 2000;21:514-50.

9. Norwitz ER, Lye SJ. Biology of parturition. In: Creasy RK, Resnick R, Iams JD, editors. Creasy \& Resnick's Maternal-Fetal Medicine. 6th ed. Philadelphia: Elsevier. 2009:69-85.

10. Society for Maternal Fetal Medicine Publications Committee, authors. ACOG Committee Opinion number 419 October 2008 (replaces no. 291, November 2003). Use of progesterone to reduce preterm birth. Obstet Gynecol. 2008;112:963-5.

11. Romero R. Vaginal progesterone to reduce the rate of preterm birth and neonatal morbidity: a solution at last.Women's Health. 2011;7:501-4.
12. Chwalisz K, Shi Shao O, Neff G, Elger J. The effect of antigestagen ZK 98, 199 on the uterine cervix. Acta Endocrinol. 1987;283:113.

13. Norman J. Antiprogesterones. Br J Hosp Med. 1991;45:372-5.

14. Elliott CL, Brennand JE, Calder AA. The effects of mifepristone on cervical ripening and labor induction in primigravidae. Obstet Gynecol. 1998;92:804-9.

15. Gamze, Cidgem S, Senol K. Evaluation of cervix by TAS TVS in $2^{\text {nd }}$ trimester. J Obstet Gynecol India. 2005;55(4).

16. Romero R, Nicolaides K, Conde-Agudelo A, Tabor A, O'Brien JM, Cetingoz E. Vaginal progesterone in women with an asymptomatic sonographic short cervix in the midtrimester decreases preterm delivery and neonatal morbidity: a systematic review and metaanalysis of individual patient data. Am J Obstet Gynecol. 2012;206(124.e1-19).

17. Creasy GW, Romero R, Hassan S. The Effect of Vaginal Progesterone Administration in the Prevention of Preterm Birth in Women With a Short Cervix, 2012. [Vaginal Progesterone Bioadhesive Gel (Prochieve) ${ }^{\circledR}$ Extending Gestation A New Therapy for Short Cervix - Trial (PREGNANT Short Cervix - Trial)].

18. Timor- Tritsch I, Boozarjomehri E, Maskowski Y, Monteagudo A, Chao CR. Can a snap shot saggital view of the cervix by transvaginal usg predict active preterm labour? Am J Obstet Gynecol. 1996;174:990-5.

19. Da Fonseca EB, Bittar RE, Carvalho MH, Zugaib M. Prophylactic administration of progesterone by vaginal suppository to reduce the incidence of spontaneous preterm birth in women at increased risk: a randomized placebo-controlled double-blind study. Am J Obstet Gynecol. 2003;188:419-24.

Cite this article as: Mohapatra K, Ghosh S, Dash R, Sahoo B. Role of vaginal progesterone in reducing the rate of preterm labour in women with a sonographic short cervixInt J Reprod Contracept Obstet Gynecol 2015;4:1793-7. 